\title{
BLICKDIAGNOSE-QUIZ
}
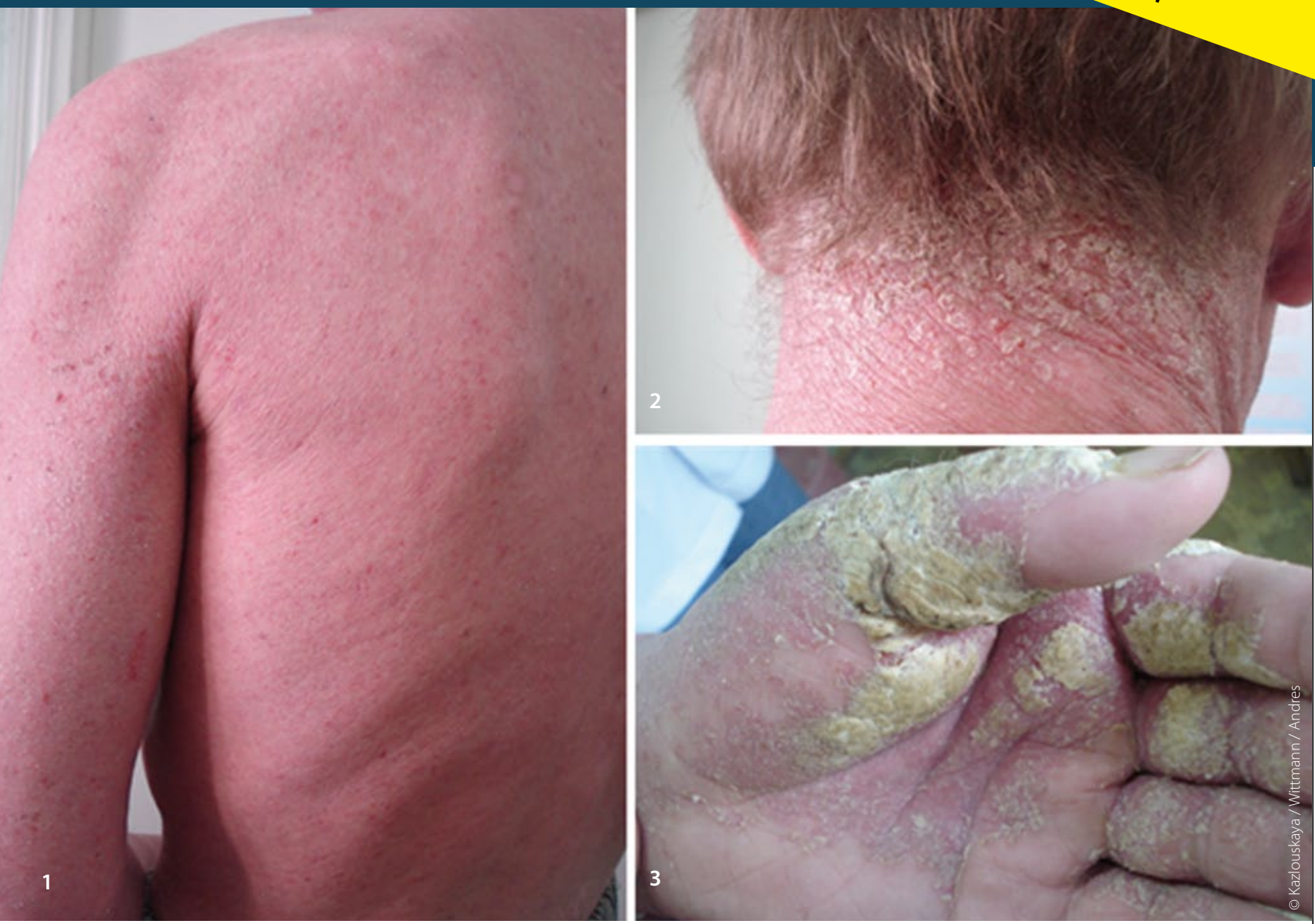

Rötung, Schuppung, Plaques

\section{Erkennen Sie diese Dermatose?}

Ein 28-jähriger Mann stellte sich in der dermatologischen Klinik mit einer generalisierten Rötung und Schuppung des äußeren Integuments vor. Die Schleimhäute waren frei, jedoch fanden sich betont an beiden Handflächen erythrosquamöse und mit fest anhaftenden Krusten belegte Plaques, die relativ scharf zur Umgebung begrenzt waren (Abb. 1-3). Diese Hautveränderungen hätten langsam progredient über einen Zeitraum von einem halben Jahr stetig zugenommen.

\section{Handelt es sich hier um}
a. ein Ekzem
b. eine Psoriasis
c. eine infektiöse Dermatose?

Auflösung auf Seite 72

\section{Weitere Infos auf springermedizin.de}

